\title{
DIREITO DAS SUCESSÕES NA ERA VIRTUAL: A QUESTÃO DA HERANÇA DIGITAL
}

\author{
Guilherme Galhardo Antonietto ${ }^{1}$ \\ Júlio César Franceschet ${ }^{2}$ \\ Edmundo Alves de Oliveira ${ }^{3}$
}

\begin{abstract}
Resumo
Frente ao contexto de transformação do direito sucessório, discute a possibilidade ou não das redes sociais e do chamado acervo digital compor a herança do falecido, transmitindo-a para seus herdeiros através da sucessão legítima. Questiona-sem se o direito sucessório viola o direito à privacidade do morto ou se a mesma é apenas um respeito ao direito à herança dos herdeiros. Neste contexto, o objetivo foi analisar tal questão à luz dos documentos e institutos legais. Evidenciou-se que o tratamento legal vigente sobre o tema é insuficiente frente à sua complexidade.
\end{abstract}

Palavras-chave: Redes Sociais; Internet; Propriedade; Testamento; Direito Civil;

\section{PROBATE AND SUCCESSION LAW IN THE VIRTUAL AGE: THE ISSUE OF DIGITAL INHERITANCE}

\begin{abstract}
Faced with the changing context of inheritance law, he discusses the possibility or not of social networks and the so-called digital collection to compose the deceased's inheritance, transmitting it to his heirs through legitimate succession. It is questioned whether the right of succession violates the deceased's right to privacy or whether it is only a respect for the inheritance right of the heirs. In this context, the objective was to analyze this issue in the light of legal documents and institutes. It became evident that the current legal treatment on the subject is insufficient in view of its complexity.
\end{abstract}

Keywords: Social Networks; Internet; Property; Testaments; Civil Right;

\section{INTRODUÇÃO}

Nota-se que, atualmente, são indiscutíveis os efeitos decorrentes do desenvolvimento da ciência e da tecnologia na sociedade. Na medida que se verificam inúmeros avanços tecnológicos, também surgem novos problemas que colocam o ser humano em evidência. Este é o caso por exemplo da herança digital, com ênfase especial no

\footnotetext{
${ }^{1}$ Advogado, especialista em Direito Civil pela PUC-MG, Mestrando em Direito pela UNIARA, Araraquara/SP, Brasil, guilherme@galhardoadvocacia.com.br.

${ }^{2}$ Doutor em Direito Civil pela Universidade de São Paulo. Mestre em Direito Civil pela Universidade do Estado do Rio de Janeiro. Professor no curso de graduação em Direito e no programa de Mestrado Profissional em Direito da Universidade de Araraquara, Araraquara/SP, Brasil, jcfranceschet@ uniara.edu.br.

${ }^{3}$ Doutor em sociologia pela Unesp, coordenador do programa de mestrado profissional em direito e gestão de conflito e professor da universidade de Araraquara - UNIARA. Email edmundoedmundo@gmail.com.
} 
gerenciamento de redes sociais e de canais de entretenimento.

Esse caráter especial é evidenciado ainda pela constatação de que contemporaneamente há uma ampla exposição da vida em âmbito cibernético. Essa é uma característica da vida social do século XXI, da chamada sociedade pós-moderna e esta mesma conexão é objeto de conflito pós mortem, sendo esse o contexto de realização da pesquisa. Neste contexto, parece ser oportuno o aprofundamento do estudo sobre os mecanismos de proteção judicial da pessoa humana e de reconhecimento de direitos essenciais, com ênfase, principalmente, nos mecanismos extrajudiciais aplicados na solução de conflitos e nos instrumentos e técnicas de gestão de conflitos.

Assim sendo, em todo esse contexto de transformação do direito sucessório é que se chega à discussão sobre a possibilidade ou não das redes sociais e do chamado acervo digital (muitas vezes com alto valor econômico) compor a herança do falecido, transmitindo-a para seus herdeiros através da sucessão legítima. O conceito de herança, conforme melhor doutrina, é a de ser o patrimônio do falecido, englobando todo o conjunto de direitos e deveres transmitidos aos herdeiros legítimos ou testamentários, com exceção daqueles que forem personalíssimos ou inerentes à pessoa do de cujus (DINIZ, 2012, p. 77).

Quanto à transmissão dos referidos bens através da sucessão testamentária não existe muita polêmica. O Código Civil é expresso ao admitir testamentos mesmo que estes contenham apenas disposições não patrimoniais. Assim, se o testador quiser, através do ato de disposição de última vontade, transmitir suas senhas, redes sociais, bem como todo seu acervo digital, poderá fazê-lo por testamento. Caso os bens possuam valor econômico, sustenta-se a necessidade de observância do respeito à legítima dos herdeiros necessários. Nesse sentido, como avaliar os bens do acervo digital do falecido? Quanto vale um canal no YouTube com 2 milhões de inscritos? Ou uma conta no instagram com 5 milhões de seguidores?

A maior problemática reside quando o falecido não deixa testamento, não dispondo sobre o destino dos seus perfis pessoais, fotos e vídeos publicados, etc, devido à aparente (ou não) conflito entre $\mathrm{o}$ direito à herança e o direito à intimidade, ambos previstos constitucionalmente, bem como os direitos da personalidade previstos no Código Civil. Assim, questiona-se: caso o falecido não disponha como última vontade sobre seu acervo digital, ele deverá compor a herança de forma indivisível até sua efetiva partilha ou os servidores deverão excluir o conteúdo após a constatação do óbito do titular? Sendo assim, o objetivo foi analisar os projeto de lei sobre a temática herança digital, bem como meios para 
evitar futuros conflitos e desavenças entre herdeiro.

Evidencia-se que o tema da pesquisa é de extrema importância, sendo um tópico contemporâneo, tendo em vista o fato de a sociedade do século XXI estar conectada às redes sociais que, por sua vez, revolucionaram a forma com que as pessoas interagem e se comunicam entre si, trazendo consigo novos desafios e questionamentos jurídicos.

\section{DA SUCESSÃO NO DIREITO BRASILEIRO}

A Constituição Federal, em seu art. $5^{\circ}, \mathrm{XXX}$, prevê o direito à herança como um direito fundamental. Dessa forma, esse direito assegurado pela Carta Magna tem passado por diversas discussões e alterações nos últimos anos. Cite-se, por exemplo, a declaração de inconstitucionalidade pelo STF do artigo 1.790 do Código Civil nos Recursos Extraordinários $n^{\circ} 646.721$ e $n^{\circ} 878.694$, sob o argumento de ser contra a Constituição a diferenciação entre a sucessão do companheiro e do cônjuge que pregava o referido artigo, incluindo, portanto, mesmo que de maneira indireta, o companheiro no rol dos herdeiros necessários, na mesma posição do cônjuge, prevista no artigo 1.829 do Código Civil.

Outra transformação/discussão que vem sofrendo o direito sucessório se dá em relação à questão objetiva da herança, ou seja, o que pode e o que não pode compor os bens do morto, o que deve ser transmitido para os seus herdeiros e o que deve desaparecer junto com seu último suspiro de vida, o que pode ser objeto de testamento e o que está vedado de sê-lo.

O Código Civil de 1916, por exemplo, pregava em seu artigo 1.626 que o testamento somente poderia ter conteúdo patrimonial ao dispor que "considera-se testamento o ato revogável pelo qual alguém, de conformidade com a lei, dispõe, no todo ou em parte, do seu patrimônio, para depois da sua morte"(BRASIL, 1916). Alterando tal percepção, o Código Civil de 2002, por sua vez, dispõe em seu art. 1.857, § 2o que: "São válidas as disposições testamentárias de caráter não patrimonial, ainda que o testador somente a elas se tenha limitado" (BRASIL, 2002).

Ressalta-se que, através da sucessão legítima prevista no artigo 1.829 do Código Civil, a lei faz uma presunção de vontade de como o falecido dividiria seu patrimônio após sua morte. Assim, após a decisão do STF referida anteriormente, deve-se ler o mencionado artigo incluindo o companheiro ou a companheira nos incisos I, II e III. Dessa forma, a sucessão legítima defere-se na ordem seguinte: I - aos descendentes, em concorrência com o 
cônjuge ou companheiro sobrevivente, salvo se o regime do casamento/união estável for o regime da comunhão universal, ou o da separação obrigatória de bens; ou se, no regime da comunhão parcial, o autor da herança não houver deixado bens particulares; II - aos ascendentes, em concorrência com o cônjuge ou companheiro; III - ao cônjuge ou companheiro sobrevivente; IV - aos colaterais até o $4^{\circ}$ grau.

Através da sucessão legítima prevista no artigo 1.829 do Código Civil, a lei faz uma presunção de vontade de como o falecido dividiria seu patrimônio após sua morte. Assim, após a decisão do STF referida anteriormente, deve-se ler o mencionado artigo incluindo o companheiro ou a companheira nos incisos I, II e III. Assim sendo, a sucessão legítima defere-se na ordem seguinte: I - aos descendentes, em concorrência com o cônjuge ou companheiro sobrevivente, salvo se o regime do casamento/união estável for o regime da comunhão universal, ou o da separação obrigatória de bens; ou se, no regime da comunhão parcial, o autor da herança não houver deixado bens particulares; II - aos ascendentes, em concorrência com o cônjuge ou companheiro; III - ao cônjuge ou companheiro sobrevivente; IV - aos colaterais até o $4^{\circ}$ grau.

Desta forma, a lei, através do artigo acima, faz uma presunção de como o de cujus teria dividido o seu patrimônio após a morte, regrando a sucessão quando não houver testamento, ou se, existindo, for declarado inválido, ineficaz ou não abranger a totalidade dos bens deixados pelo falecido, sendo chamada de sucessão legítima. Por outro lado, a sucessão testamentária tem origem no ato de última vontade do morto, sendo um exercício da autonomia privada, podendo ser feito através de testamento ou codicilo (TARTUCE, 2019, p. 1318), sempre respeitando-se a parte legítima dos herdeiros necessários, a qual não poderá ser objeto de testamento, mas somente a parte disponível do autor da herança.

O Código Civil de 1916 no seu artigo 1626 conceituou testamento como: “(...) o ato revogável pelo qual alguém, de conformidade com a lei, dispõe, no todo ou em parte, do seu patrimônio, para depois de sua morte". Porém, o atual Código Civil não trouxe uma definição de testamento, cabendo tal tarefa a doutrina contemporânea, podendo ser definido como um “(...) um negócio jurídico pelo qual uma pessoa dispõe de seus bens, no todo ou em parte, ou faz determinações não patrimoniais, para depois de sua morte" (VELOSO, 2012, p. 2089).

A propósito, ensina Pontes de Miranda, em licação compatível com o Código Civil de 2002: 
Trata-se de declaração unilateral de vontade, não receptícia (não existe qualquer aceitante ou recebedor da declaração de última vontade). Ninguém é comparte, ou destinatário. No testamento público ou no testamento cerrado, o tabelião recebe o que se lhe dita, sem participar do negócio jurídico em si: inscreve, quiçá escreva pelo testador. Mero instrumento, com funções acauteladoras. Tanto assim que poderia o disponente escrever o testamento particular: seria válido. A sombra que se vê, o outro polo da relação jurídica, é a mesma dos outros negócios jurídicos unilaterais, nos direitos reais, nas aquisições não consensuais da propriedade. A voz social, que obriga ao prometido, ou faculta a disposição ou reconhece o nascer do direito de propriedade. Por isso mesmo, para ser válido o testamento, não é de mister que dele se saiba: opera os seus efeitos, à abertura da sucessão, ainda que os herdeiros e legatários nada saibam. Mas ainda: não é preciso, para sua perfeição, que faleça o testador, menos ainda que nas cláusulas consintam os beneficiados, o que importa é que o testador tenha capacidade para fazê-lo e o faça dentro da lei. Tanto ele independe da morte, ou de qualquer ato de outrem, que se lhe há de aplicar, e só lhe pode exigir, a lei do tempo em que foi feito. Enlouqueça o testador, mude-se a legislação, nada importa: estava perfeito quando se fez (PONTES DE MIRANDA, 1972, P. 72).

A realização do testamento não é só uma declaração de última vontade do falecido, mas também um meio de se evitarem futuros conflitos entre os herdeiros, bem como o conflito entre o direito à privacidade e intimidade do falecido com o direito à herança dos seus sucessores. O testamento, sendo o exercício da autonomia privada, deixa expressa a intenção volitiva do falecido, ou seja, quais bens ele quer transmitir e para quem ele quer transmitir, podendo ainda fazer disposições não patrimoniais, como, por exemplo, dispor sobre suas senhas, redes sociais, etc. Portanto, com o testador expressamente dispondo sobre o assunto, evita-se a discussão sobre a violação da privacidade e da intimidade do falecido em decorrência da transmissão do seu acervo digital. Como bem assevera Roxana Cardoso Borges, o direito de personalidade não é disponível em sentido estrito, mas sim apenas as expressões do uso do direito da personalidade, ou seja, são os aspectos patrimoniais, de forma limitada, que podem ser objeto de transmissão, e não o direito em si (2005, p. 11).

Ainda, sob a ótica de evitar conflitos entre os herdeiros, como já explanado acima, o autor da herança pode dispor de metade de seu patrimônio livremente, ficando a outra parte resguardada pela legítima, isso se houver herdeiros necessários; ausentes herdeiros dessa natureza, pode dispor livremente. Assim sendo, pelo menos em relação a 50\% da sua herança líquida, o testador pode evitar futuras discussões e brigas entre herdeiros sobre essa parte de seu patrimônio, pois, caso este ato siga todos os ditames legais, ele deverá ser 
necessariamente observado quando da morte do autor, não havendo o que se discutir entre seus herdeiros.

Quando o testador opta pela realização do testamento na forma pública, ele deverá seguir os mandamentos dos artigos 1.864 a 1.867 do Código Civil, ou seja, ser escrito por tabelião ou por seu substituto legal em seu livro de notas, de acordo com as declarações do testador, podendo este servir-se de minuta, notas ou apontamentos. Depois de lavrado o instrumento, este ser lido em voz alta pelo tabelião ao testador e a duas testemunhas, a um só tempo, ou pelo testador, se o quiser, na presença destas e do oficial, bem como ser o instrumento, em seguida à leitura, assinado pelo testador, pelas testemunhas e pelo tabelião.

Isto posto, como o testamento público é feito perante o tabelião, este tem o dever de zelar pela segurança jurídica, bem como o dever de orientação das partes envolvidas no negócio que ele chancela. Não é a toa que a doutrina define a atuação notarial como sendo útil e relevante para a prevenção de conflitos, sendo o notário um agente de justiça preventiva e paz social (LOUREIRO, 2016, p. 113).

Portanto, é cristalina a importância que o aconselhamento dos notários têm na prevenção de conflitos. Ao lavrarem os testamentos públicos dos testadores, informando-os sobre a possibilidade de incluírem os seus bens de acervo digital, bem como os rendimentos advindos das diversas redes sociais, YouTube, etc, estarão prevenindo futuros litígios e discussões entre os herdeiros. Nesse sentido, ensina Loureiro que:

Com efeito, o conselho ou assessoramento notarial, é a expressão específica dessa atividade preventiva de litígios, já que se destina a informar o usuário sobre todos os aspectos do assunto jurídico em questão e a conformar a verdadeira vontade das partes. Essa assessoria representa, por suas características peculiares, uma autêntica cultura de prevenção de litígios. Tendo em vista o princípio da legalidade que rege a função notarial, o conselho prestado pelo notário deve levar em conta o respeito ao ordenamento jurídico (aspecto característico da função pública), ao mesmo tempo em que constitui um serviço gratuito aos particulares, participantes do mercado jurídico (aspecto próprio da profissão liberal). Ademais, o conselho notarial, conforme já foi visto, é imparcial em relação às partes implicadas, neutro em relação a qualquer influência inadequada, é dirigido às necessidades específicas das partes e se estende, sem restrição, a todas as matérias jurídicas, independentemente da redação de documentos notariais (art. $7^{\circ}$, parágrafo único, da Lei 8.935/1994). Finalmente o conselho está amparado pela responsabilidade específica do notário (art. 22), que não é mero subministrador de informação jurídica, e sim garante da legalidade, da pertinência e da fiabilidade do assessoramento oferecido (2016, p. 116). 
Sobre o aspecto objetivo da herança, conforme o artigo 1.791 do Código Civil, a mesma defere-se como um todo unitário, mesmo que existam vários herdeiros, estando incluído neste montante os bens do acervo digital. Ressalta-se que muitos desses bens estão protegidos pela lei 9.610/1998, podendo ser citados como exemplo as obras audiovisuais, sonorizadas ou não, inclusive as cinematográficas, as obras fotográficas e as produzidas por qualquer processo análogo ao da fotografia; as obras de desenho, pintura, gravura, escultura, litografia e arte cinética, as ilustrações, cartas geográficas e outras obras da mesma natureza, etc.

\section{DA HERANÇA DIGITAL}

Hoje em dia existem países que consideram o acesso à internet como um direito fundamental. Tem-se como exemplo a Finlândia, que foi um dos primeiros a reconhecer o que a universalidade do acesso à internet banda larga era um direito fundamental (FINLÂNDIA, 2010). Ainda, no longínquo ano de 2001, a Grécia realizou uma revisão constitucional, incluindo o artigo $5^{\circ}$ que dispõe que todas as pessoas têm o direito de participar na sociedade da informação, sendo que a facilitação do acesso a informações transmitidas por via eletrônica, bem como da produção, intercâmbio e difusão os mesmos, constitui uma obrigação do Estado (GRÉCIA, 2008, p. 23).

Para se ter uma ideia, em 2016, a Internet era utilizada em 69,3\% dos domicílios permanentes do País e este percentual aumentou para 74,9\%, em 2017 (IBGE: 2018). Portanto, não podemos negligenciar que a internet, redes sociais e bens digitais são uma realidade em nossa sociedade e devem ser abrangidos e estudados pelo Direito Civil, mais especificamente o Direito Sucessório.

Cada vez mais a sociedade está conectada através das redes sociais e, assim sendo, também cresce o número de pessoas que trabalham através delas: desde blogueiras(os), os chamados influencers, até celebridades que se utilizam dessas ferramentas para gerar renda através de propagandas de produtos na rede social Instagram, perfis comerciais de lojas totalmente digitais e até a criação de canais no YouTube que geram milhares de dólares de renda por vídeo através da monetização das visualizações. Assim, nem a lei de 1998 e nem Código Civil estão atualizados a ponto de tratarem de maneira satisfatória sobre o destino do acervo digital dos falecidos, tenha ele valor monetário ou não. 
Com algum esforço hermenêutico podemos encaixar os vídeos monetizados produzidos por influencers/youtubers e no conceito de "obras audiovisuais" da lei 9.610/1998, estando, portanto, tal conteúdo protegido pela referida lei, bem como as fotos e propagandas que geram renda através do instagram podem ser abrangidos pelo conceito de "fotografia" também presente na lei de 1998.

Porém, uma vez incluídos os bens do acervo digital na lei sobre direitos autorais, quais direitos transmitem-se aos herdeiros? Em linhas gerais o autor possui dois tipos de direitos relacionados às suas obras: morais e patrimoniais. Os últimos estão previstos nos artigos 28 e 29 da lei ora abordada, in verbis: "Art. 28. Cabe ao autor o direito exclusivo de utilizar, fruir e dispor da obra literária, artística ou científica." e "Art. 29. Depende de autorização prévia e expressa do autor a utilização da obra, por quaisquer modalidades, tais como: (...).

Os direitos patrimoniais, conforme artigo 41 da Lei 9.610/98, vigoram por 70 anos após sua morte: "Art. 41. Os direitos patrimoniais do autor perduram por setenta anos contados de $1^{\circ}$ de janeiro do ano subseqüente ao de seu falecimento, obedecida a ordem sucessória da lei civil. Parágrafo único. Aplica-se às obras póstumas o prazo de proteção a que alude o caput deste artigo."

Porém, em relação aos direitos morais, a questão não é tão simples. A mesma lei em seu artigo 24 prevê como direitos dessa espécie, entre outros, o de reivindicar, a qualquer tempo, a autoria da obra; o de ter seu nome, pseudônimo ou sinal convencional indicado ou anunciado, como sendo o do autor, na utilização de sua obra; o de conservar a obra inédita; o de assegurar a integridade da obra, opondo-se a quaisquer modificações ou à prática de atos que, de qualquer forma, possam prejudicá-la ou atingi-lo, como autor, em sua reputação ou honra; bem como o de modificar a obra, antes ou depois de utilizada e ainda prega que, pela morte do autor, transmitem-se a seus sucessores os referidos direitos.

Assim, quando o autor falecer, só serão transmitidos aos herdeiros os direitos morais dos incisos I a IV do artigo acima. Portanto, como vimos acima, os herdeiros terão, durante 70 anos, o direito de utilizar, fruir, dispor e autorizar o uso da obra de seu antecessor. Nesse sentido, o acervo digital será composto por bens que possuem valor econômico (e-books, músicas, produções de autoria própria, rendimentos advindos de monetização de vídeos no YouTube e de fotos/posts em instagram, etc, ou seja, todo conteúdo patrimonial armazenado/produzido de maneira digital) e aqueles que não o possuem e, portanto, não 
devem integrar o monte-mor, sendo aqueles mais ligados à personalidade do falecido e sua privacidade (conversas com outros usuários, e-mails pessoais, fotos privadas, redes sociais sem valoração econômica, etc, ou seja, todo conteúdo existencial).

Quanto aos bens do primeiro grupo, é imperioso se afirmar que eles deverão compor a herança. Ora, se o direito à herança é um direito fundamental garantido constitucionalmente e, ao mesmo tempo, se caracteriza por abranger os direitos e deveres do falecido, excetuados os personalíssimos, tolher os herdeiros de herdá-los seria uma afronta à própria Constituição Federal. Por outro lado, também não se pode permitir que os herdeiros tenham acesso e devassem a vida pessoal cibernética do falecido, com amplo e irrestrito acesso às suas conversas, e-mails, etc, sem motivo judicialmente justificável, pois violaria frontalmente também o seu direito à privacidade garantido constitucionalmente, bem como o direito à privacidade e à intimidade de terceiros).

A propósito, prevê a Constituição Federal, em seu artigo 5, inc. X, que "são invioláveis a intimidade, a vida privada, a honra e a imagem das pessoas, assegurado o direito a indenização pelo dano material ou moral decorrente de sua violação". Vale citar ainda que a Constituição Federal cuida da proteção de dados no mesmo artigo, em seu inciso XII, dispondo que é “inviolável o sigilo da correspondência e das comunicações telegráficas, de dados e das comunicações telefônicas, salvo, no último caso, por ordem judicial, nas hipóteses e na forma que a lei estabelecer para fins de investigação criminal ou instrução processual penal".

A legislação infraconstitucional também prega a inviolabilidade da privacidade e dos dados do indivíduo. A recém editada Lei Geral de Proteção de Dados (Lei 13.709/2018) prega em seu artigo $2^{\circ}$ que "a disciplina da proteção de dados pessoais tem como fundamentos: o respeito à privacidade, a autodeterminação informativa, a liberdade de expressão, de informação, de comunicação e de opinião, a inviolabilidade da intimidade, da honra e da imagem, o desenvolvimento econômico e tecnológico e a inovação, a livre iniciativa, a livre concorrência e a defesa do consumidor, os direitos humanos, o livre desenvolvimento da personalidade, a dignidade e o exercício da cidadania pelas pessoas naturais”.

O Marco Civil da Internet (Lei 12.965/2014) não possui espírito diferente; em seu artigo $7^{\circ}$ cuida da inviolabilidade da privacidade e dos dados pessoais, salvo por ordem judicial, sendo assegurado ao usuário o direito à não violação da intimidade e da vida privada, bem como sua proteção e indenização pelo dano material ou moral decorrente de sua 
violação. Protege ainda o sigilo do fluxo de suas comunicações pela internet, proibindo o não fornecimento a terceiros de seus dados pessoais, inclusive registros de conexão, e de acesso a aplicações de internet, salvo mediante consentimento livre, expresso e informado ou nas hipóteses previstas em lei.

Como todo direito fundamental, o direito à privacidade e intimidade possuem restrições. Porém, como se viu, tais direitos somente pode ser restringidos em situações que assim justifiquem. Nesse sentido, não é assegurado de modo absoluto a inviolabilidade da intimidade, da vida privada, da honra e da imagem das pessoas, sendo consideradas legítimas tais intervenções quando estas se mostrarem adequadas, proporcionais e necessárias para fomentar outros princípios constitucionais, não existindo outro meio eficaz em sentido estrito, bem como promoverem a realização de princípios cujas razões, no caso concreto, são mais fortes que os decorrentes do direito à privacidade (NOVELINO, 2019).

$\mathrm{Na}$ Alemanha, o leading case que abordou o assunto herança digital foi o processo BGH III ZR 183/17, julgado em 12/07/2018 (ALEMANHA, 2018). No referido caso, uma adolescente de 15 anos faleceu em um acidente no metrô de Berlim em 2012, porém, as circunstâncias da morte não haviam sido totalmente esclarecidas, e passou-se a cogitar a hipótese de suicídio. Os pais da adolescente então foram impedidos pelo Facebook de acessar a conta de sua filha por seu perfil ter sido transformado em "memorial" (fato este possível até hoje, quando uma pessoa informa a empresa sobre o falecimento de um de seus usuários). A transformação em "memorial", como a própria empresa define, "manterá uma conta segura, pois impedirá que outras pessoas tenham acesso a ela:

\begin{abstract}
A transformação em memorial manterá uma conta segura, pois impedirá que outras pessoas entrem nela. A conta continuará visível no Facebook, mas a única pessoa que pode gerenciar uma conta transformada em memorial é o contato herdeiro selecionado pelo titular. Se o titular da conta não tiver selecionado um contato herdeiro, ela não será administrada ativamente por ninguém após a solicitação de transformação em memorial. Se o titular da conta tiver solicitado a exclusão permanente de sua conta após o falecimento, removeremos a conta quando ficarmos cientes de que ele faleceu (FACEBOOK, 2020).
\end{abstract}

Em primeiro grau (Landesgericht Berlin) do leading case mencionado, o juiz ordenou que o Facebook desse acesso à conta da adolescente falecida, argumentando ainda que os herdeiros também recebem a herança digital do falecido, inclusive o contrato firmado entre o morto e a rede social. Já em segunda instância, o Tribunal Kammergericht reformou a 
decisão dizendo que, apesar do fato de a adolescente ter firmado um contrato com o Facebook e, por sua vez, os direitos e deveres inerentes a contratos serem transmissíveis, não estava clara a questão de transmissão de conteúdo de bens personalíssimos.

Por fim, a família recorreu ao Bundesgerichtshof (BGH), que deu razão aos pais, dando-lhes acesso à conta de sua falecida filha, em razão do princípio da sucessão universal, tratada no § 1922 I BGB que rege o mundo analógico e também o digital, segundo a qual todo o patrimônio do falecido é transmitido a seus sucessores, exceto aquelas relações que se devam extinguir por sua natureza, por força de lei, acordo ou pela vontade do autor da herança.

No Brasil a matéria está longe de estar pacificada, tanto assim o é que já foram apresentados no Congresso Nacional três projetos de lei sobre o assunto: o PL 4.847/2012, PL 7.742/2017 e o PL 5820/2019. O projeto de 2012 visava acrescentar o Capítulo II-A e os arts. 1.797-A a 1.797-C ao Código Civil, para prever que a herança digital seria deferida como o conteúdo intangível do falecido, abrangendo tudo o que é possível guardar ou acumular em espaço virtual, incluindo senhas, redes sociais, contas da Internet, bem como qualquer bem e serviço virtual e digital de titularidade do falecido.

Ainda o mesmo projeto prevê que, se o falecido, tendo capacidade para testar, não o tiver feito, a herança será transmitida aos herdeiros legítimos. Nestes casos, caberia ao herdeiro definir o destino das contas do falecido, transformá-las em memorial, deixando o acesso restrito a amigos confirmados e mantendo apenas o conteúdo principal, apagar todos os dados do usuário ou remover a conta do antigo usuário.

Como percebe-se do projeto acima, ele visava introduzir no Código Civil expressamente o conceito de herança digital, abrangendo senhas, redes sociais, contas da internet e qualquer bem e serviço virtual e digital de titularidade do falecido, transmitindo-se tudo isso automaticamente pelo princípio de saisine, como ocorre com os bens do mundo físico. Assim, caberia ao herdeiro dar a destinação que bem entendesse ao acervo digital recebido.

Já o projeto de lei de 2017 visava acrescentar o artigo 10-A ao Marco Civil da Internet (lei 12.965/2014), assim dispondo:

Art. 10-A. Os provedores de aplicações de internet devem excluir as respectivas contas de usuários brasileiros mortos imediatamente após a comprovação do óbito.

$\S 1^{\circ}$ A exclusão dependerá de requerimento aos provedores de aplicações de 
internet, em formulário próprio, do cônjuge, companheiro ou parente, maior de idade, obedecida a linha sucessória, reta ou colateral, até o segundo grau inclusive.

$\S 2^{\circ}$ Mesmo após a exclusão das contas, devem os provedores de aplicações de internet manter armazenados os dados e registros dessas contas pelo prazo de 1 (um) ano, a partir da data do óbito, ressalvado requerimento cautelar da autoridade policial ou do Ministério Público de prorrogação, por igual período, da guarda de tais dados e registros.

$\S 3^{\circ}$ As contas em aplicações de internet poderão ser mantidas mesmo após a comprovação do óbito do seu titular, sempre que essa opção for possibilitada pelo respectivo provedor e caso o cônjuge, companheiro ou parente do morto indicados no caput deste artigo formule requerimento nesse sentido, no prazo de um ano a partir do óbito, devendo ser bloqueado o seu gerenciamento por qualquer pessoa, exceto se o usuário morto tiver deixado autorização expressa indicando quem deva gerenciá-la (BRASIL, 2017)

Nesta segunda proposta legislativa, propõe-se que as contas/redes sociais de usuários brasileiros mortos devem ser imediatamente excluídas após a comprovação do óbito, fato este que dependerá de requerimento de algum herdeiro/parente. Porém, mesmo após excluída a conta, o provedor deverá armazenar seus dados e registros pelo prazo de um ano, salvo requerimento cautelar da autoridade policial ou Ministério Público. Claramente o parágrafo segundo da proposta visa resguardar possíveis provas que as redes sociais do falecido contenham para a elucidação de crimes.

Conforme o projeto de lei acima, as contas/redes sociais poderão ser mantidas quando existir essa opção dada pelo respectivo provedor, somado a um pedido expresso do cônjuge, companheiro ou parente do morto no prazo de um ano. Frise-se que os herdeiros não terão acesso para gerenciar a conta/rede, a não ser que o falecido tenha deixado autorização expressa, indicando quem irá gerir a conta (através de um testamento, por exemplo).

Por fim, o projeto de lei mais recente (PL 5820/2019), visa alterar o artigo 1.881 do Código Civil, no seguinte sentido:

Art. 1.881. Toda pessoa capaz de testar poderá, mediante instrumento particular, fazer disposições especiais sobre o seu enterro, bem como destinar até $10 \%$ (dez por cento) de seu patrimônio, observado no momento da abertura da sucessão, a certas e determinadas ou indeterminadas pessoas, assim como legar móveis, imóveis, roupas, joias entre outros bens corpóreos e incorpóreos.

$\S 1^{\circ}$ A disposição de vontade pode ser escrita com subscrição ao final, ou ainda assinada por meio eletrônico, valendo-se de certificação digital, dispensando-se a presença de testemunhas e sempre registrando a data de efetivação do ato.

$\S 2^{\circ}$ A disposição de vontade também pode ser gravada em sistema digital de 
som e imagem, devendo haver nitidez e clareza nas imagens e nos sons, existir a declaração da data de realização do ato, bem como registrar a presença de duas testemunhas, exigidas caso exista cunho patrimonial na declaração.

$\$ 3^{\circ}$ A mídia deverá ser gravada em formato compatível com os programas computadorizados de leitura existentes na data da efetivação do ato, contendo a declaração do interessado de que no vídeo consta seu codicilo, apresentando também sua qualificação completa e das testemunhas que acompanham o ato, caso haja necessidade da presença dessas.

$\S 4^{\circ}$ Para a herança digital, entendendo-se essa como vídeos, fotos, livros, senhas de redes sociais, e outros elementos armazenados exclusivamente na rede mundial de computadores, em nuvem, o codicilo em vídeo dispensa a presença das testemunhas para sua validade.

$\S 5^{\circ} \mathrm{Na}$ gravação realizada para fim descrito neste dispositivo, todos os requisitos apresentados tem que ser cumpridos, sob pena de nulidade do ato, devendo o interessado se expressar de modo claro e objetivo, valendo-se da fala e vernáculo Português, podendo a pessoa com deficiência utilizar também a Língua Brasileira de Sinais (LIBRAS) ou de qualquer maneira de comunicação oficial, compatível com a limitação que apresenta."

Art. $2^{\circ}$ Esta Lei entra em vigor na data de sua publicação (BRASIL, 2019).

Assim, vê-se que o projeto do ano de 2019 até traz certo avanço para o direito sucessório ao tentar acabar com a polêmica do quantum do patrimônio do falecido pode ser disposto através de codicilo (ponto este não previsto hoje no Código Civil e gerador de muita polêmica na doutrina e jurisprudência) e ao possibilitar a realização do mesmo através de imagem e som, além de definir o conceito de herança digital.

Ocorre que nenhum dos três projetos aprofundam-se na matéria como deveriam. $\mathrm{O}$ primeiro projeto basicamente devassa a vida virtual do falecido, dando total e irrestrito acesso aos herdeiros. Assim, em uma tentativa de se resguardar o direito à herança, acaba por violar e ignorar o direito à privacidade e direitos de personalidade do morto e de terceiros.

O segundo projeto, por sua vez, visando proteger a intimidade do falecido a todo custo, determina a exclusão das contas de usuários brasileiros mortos após a comprovação do óbito e requerimento do cônjuge/companheiro/parente. O terceiro projeto, por fim, visa apenas possibilitar a realização de codicilo por vídeo, definindo a herança digital como vídeos, fotos, livros, senhas de redes sociais, e outros elementos armazenados exclusivamente na rede mundial de computadores, em nuvem, não abordando o ponto crucial da questão que é o embate entre a inviolabilidade da privacidade do falecido e o direito à herança de seus sucessores, simplesmente ignorando tal fato, trazendo apenas definições e conceitos.

Desta forma, vê-se que, em nosso país, tanto a legislação atual, quanto as propostas legislativas não respondem satisfatoriamente a seguinte questão: como garantir o direito à 
sucessão legítima dos bens digitais com valoração patrimonial que pertenciam ao falecido sem violar a sua intimidade? Frise-se que, como a sucessão testamentária é uma das formas mais claras de expressão de vontade, caso o falecido deixe através de testamento suas senhas, bens de acervo digital, destinação de rendas advindas de YouTube e/ou outras redes sociais, etc, esta deverá ser respeitada, mas também estará sujeita às reduções das disposições testamentárias previstas no art. 1.967 do Código Civil de 2002.

\section{CONSIDERAÇÕES FINAIS}

O presente artigo não pretendeu esgotar todas as nuances do assunto, mas sim demonstrar que a sucessão da herança digital é muito mais complexa e exige muito mais profundidade do que os projetos de lei em tramitação dispensam à matéria. Nessas situações, temos um claro confronto entre o direito dos herdeiros à herança e o direito à privacidade do falecido e de terceiros.

Não se encontra muita polêmica quando tudo é disposto por testamento, respeitandose a legítima, independentemente dos bens/assuntos tratados ali versarem sobre bens com valoração econômica ou não. Inclusive, vislumbra-se que, ao ser realizado um testamento público, seja dever do notário aconselhar o testador a abordar em seu testamento sobre o seu acervo digital, dizendo o que deve ser transmitido e o que deve ser excluído/deletado após a sua morte, de forma a evitar conflitos entre os herdeiros, bem como uma possível decisão judicial futura que devasse sua vida virtual após a morte.

Nesse sentido, torna-se extremamente importante a figura do notário através da informação e aconselhamento do testador que muitas vezes nem se atenta ao fato de possuir bens digitais ou sobre a possibilidade de ter sua vida digital devassada após a morte. Assim, o tabelião ganha ainda mais força nos dias atuais na busca de prevenção de conflitos entre os herdeiros e entre direitos constitucionais (herança e privacidade) através de sua atuação na realização de testamentos públicos.

Porém, quando não existe disposição de última vontade do falecido, a herança digital deverá ser deferida na ordem que manda o artigo 1.829 do CC/2002, incluindo-se aqui as receitas geradas pelas redes sociais do usuário, filmes, livros, músicas, etc. Sobre os bens do acervo que sejam de estrito cunho pessoal, não suscetíveis de valoração econômica, em caso de inexistência de testamento, não deverá ser transmitida aos herdeiros, sob pena de violação da privacidade do usuário falecido sem um motivo plausível para tanto, qual seja: econômico. 
Diz-se isso, pois, em casos de pessoas "comuns", que não trabalham com redes sociais e nem geram patrimônio através delas, não existe justificativa aos olhos do direito para que os herdeiros passem a ter irrestrito acesso à toda intimidade virtual do autor da herança, respeitando-se a sua vontade, mesmo que tácita, de que a sua vida pessoal cibernética desapareça junto com seus sinais vitais, sendo opção dos herdeiros transformar as redes sociais do falecido nos chamados memoriais, caso assim as mesmas disponibilizem, sem dar acesso às conversas e intimidade do usuário.

Como bem explanado anteriormente, a inviolabilidade da intimidade e da vida privada somente pode sofrer limitações legítimas quando estas se mostrarem adequadas e necessárias frente a outros direitos constitucionais, bem como ser proporcionais aos fins que se busca. Assim sendo, não se mostram adequados os projetos de Lei abordados, muito menos proporcionais (estando ambos hoje arquivados). Isso porque, como vimos o PL 4.847/2012 ignora totalmente a vida pessoal e a intimidade virtual do falecido, dando total e irrestrito acesso aos herdeiros às senhas, redes sociais, contas da internet e qualquer bem e serviço virtual e digital de titularidade do morto.

Por outro lado, o PL 7.742/2017 manda que as contas/redes sociais do falecido devem ser excluídas após comprovação do óbito e requerimento de herdeiro ou parente, sem respeitar o direito à herança dos herdeiros em caso do morto possuir redes sociais que geram receita ou possuam valoração econômica. Desta forma, o caminho a ser seguido é a edição de um projeto de lei que considere, de maneira completa e razoável, o direito do falecido (privacidade) e direito dos herdeiros (herança).

O caminho para tanto é uma proposta legislativa que obrigue os servidores e provedores de internet, bem como as empresas donas de redes sociais que, após a constatação do óbito do falecido, não havendo testamento que aborde o assunto, e caso o mesmo aufira renda através do seu serviço (aqui incluindo redes sociais, youtube, etc) ou possua bens de valoração econômica armazenados digitalmente, a darem acesso a tais bens e continuidade aos herdeiros em relação aos proventos advindos destes meios, mas sem dar-lhes acesso a todo conteúdo pessoal/privado de intimidade do falecido, criando uma espécie de "memorial rentável”, onde os sucessores teriam acesso às rendas/proventos/exploração econômica, mas sem conseguirem acessar e-mails, caixas de mensagens, conteúdo privado do morto, salvo sob ordem judicial.

Verifica-se que tal proposição é possível pois em plataformas como o YouTube, por 
exemplo, o criador de conteúdo já possui em seu painel de usuário o quanto os seus vídeos estão lhe rendendo, bastando a empresa dar acesso aos sucessores apenas a esta parte da conta do falecido para que possam ter seu direito à herança respeitado, sem violar a privacidade do de cujus.

Por outro lado, em redes sociais como Facebook e Instagram, os criadores de conteúdo auferem renda principalmente com publicidade através de vídeos e fotos em parcerias com marcas e, como explanado acima, tais empresas já possibilitam a transformação das referidas contas em memoriais, dando acesso a um "contato herdeiro" que poderá administrar a conta, impossibilitando-o de acessar quaisquer áreas pessoais ou privadas como caixa de mensagens ou atividades pretéritas do usuário falecido, mas ainda assim possibilitando a exploração econômica da conta pelos sucessores.

\section{BIBLIOGRAFIA}

ALEMANHA, BGH III ZR 183/17. 12 de Julho de 2018.

BORGES, Roxana Cardoso. Disponibilidade dos Direitos de Personalidade e Autonomia Privada. São Paulo: Saraiva, 2005.

BRASIL, Código Civil (2002). Disponível em: Acesso em 25 de Jan. de 2020. Disponível em: http://www.planalto.gov.br/ccivil_03/leis/2002/110406.htm

BRASIL, Constituição Federal (1988). Disponível em: http://www.planalto.gov.br/ccivil_03/constituicao/constituicaocompilado.htm. Acesso em 25 de Jan. de 2020.

BRASIL, Marco Civil da Internet (2014). Disponível em: http://www.planalto.gov.br/ccivil_03/_ato2011-2014/2014/lei/112965.htm. Acesso em 25 de Jan. de 2020.

BRASIL, Lei Geral de Proteção de Dados (2018). Disponível em: http://www.planalto.gov.br/ccivil_03/_ato2015-2018/2018/lei/L13709.htm. Acesso em 25 de Jan. de 2020.

BRASIL. Câmara dos Deputados. Projeto de Lei 4847/2012 de 12 de Dezembro de 2012. Acrescenta o Capítulo II-A e os arts. 1.797-A a 1.797-C à Lei no 10.406 , de 10 de janeiro de 2002. Disponível em:

https://www.camara.leg.br/proposicoesWeb/fichadetramitacao?idProposicao=563396. Acesso em: 25 de Jan. 2020. Texto Original.

BRASIL. Câmara dos Deputados. Projeto de Lei PL 7742/2017 de 30 de Maio de 2017.

Acrescenta o art. 10-A à Lei no 12.965, de 23 de abril de 2014 (Marco Civil da Internet), a fim 
de dispor sobre a destinação das contas de aplicações de internet após a morte de seu titular.

Disponível em:

https://www.camara.leg.br/proposicoesWeb/fichadetramitacao?idProposicao=2139508.

Acesso em: 25 de Jan. 2020. Texto Original.

BRASIL. Câmara dos Deputados. Projeto de Lei PL 5820/2019 de 31 de Outubro de 2019. Dá nova redação ao art. 1.881 da Lei no 10.406 , de 2002, que institui o Código Civil..

Disponível em:

https://www.camara.leg.br/proposicoesWeb/fichadetramitacao?idProposicao=2228037.

Acesso em: 25 de Jan. 2020. Texto Original.

DINIZ, Maria Helena. Curso de Direito Civil Brasileiro. Vol 6 - direito das sucessões, 26a edição, São Paulo: Saraiva, 2012.

FACEBOOK. https://www.facebook.com/help/contact/651319028315841. Menlo Park, Califórnia, EUA, 2020

FINLÂNDIA. 1 Mbit Internet access a universal service in Finland from the beginning of July. Ministry of Transport and Communications, 2010.

GRÉCIA. The Constitution of Greece. Disponível em:

<https://www.hellenicparliament.gr/UserFiles/f3c70a23-7696-49db-9148-f24dce6a27c8/001156\%20aggliko.pdf>. Acesso em: 13 Mar. 2020.

IBGE. Pesquisa Nacional por Amostra de Domicílios Contínua. Brasília, 2018. Disponível em: https://biblioteca.ibge.gov.br/visualizacao/livros/liv101631_informativo.pdf. Acesso em: 13 Mar. 2020.

LOUREIRO, Luiz Guilherme. Manual de Direito Notarial: da atividade e dos documentos notariais. Salvador: JusPODIVM, 2016.

NOVELINO, Marcelo. Curso de Direito Constitucional. 14. ed. rev., ampl. e atual. - Salvador: Ed. JusPodivm, 2019.

PONTES DE MIRANDA, Francisco Cavalcanti. Tratado de Direito Privado. Rio de Janeiro: Borsoi, 1972.

TARTUCE, Flávio. Manual de Direito Civil. 9ª Ed. São Paulo: Método, 2019.

VELOSO, Zeno. Código Civil comentado. Coord. Ricardo Fiúza e Regina Beatriz Tavares da Silva. 8a Ed. São Paulo: Saraiva, 2012. 